\title{
Harvesting tailings from an active tailings storage facility: success and challenges - Frog's Leg mine, Evolution Mining
}

\author{
V Gopalakrishnan Evolution Mining, Australia \\ T Nester Operational Geotechs Pty Ltd, Australia \\ J Mgumbwa Operational Geotechs Pty Ltd, Australia \\ W Holtzhausen Evolution Mining, Australia
}

\begin{abstract}
This paper is an investigation report summarising a series of tests and observations conducted over a two year period as part of a feasibility study for replacing the tailings used in the cemented paste fill (CPF). The testworks were conducted at Evolution Mining's Frog's Leg mine, Kalgoorlie, which utilises undercut long-hole stoping with CPF.

The project was initiated after the tailings reclaim agreement with a third party supplier failed to be negotiated, which compelled management to explore the possibility of harvesting tailings from Evolution's Mungari Gold Operations' (MGO) newly established tailings storage facility (TSF). The feasibility study includes testing tails for CPF compatibility and liaising with TSF engineer(s) for the best extraction of tails without hindering the dam lift cycle and stability.

Access towards the centre of the TSF was an issue due to poor compaction of the surface near the decant point and this, in turn, restricted the amount of tails that could be extracted. Tailings with a fine particle size were required to reduce the void ratio in the CPF; however, these tailings had deposited towards the middle of the TSF, which was wet, resulting in the harvested tails containing excess coarse size particles. A combination of insufficient tailings available to meet the annual paste backfill requirements and the lack of fines in the tailings lead to the concept of adding screened oxide (overburden) to the extracted tails.

This paper explores the blending of oxide with tailings for CPF mix at different ratios and its effect on the final CPF product. The key findings from the study concluded that the strength of the CPF will be inversely proportional to the ratio at which the oxide is added to the CPF mix.
\end{abstract}

Keywords: tailings, harvest, blending, cemented paste fill (CPF), particle size distribution

\section{Introduction}

Frog's Leg mine is part of the Mungari Gold Operations (MGO) owned by Evolution mining and is located $20 \mathrm{~km}$ west of Kalgoorlie in the Kundana mining region. The mine uses undercut long-hole stoping with cemented paste fill (CPF) as backfill for the continuous end on retreat ore extraction. The orebody is mineralised into two orebodies, namely Mist lode towards the north and Rocket lode towards the south.

Cemented paste fill was introduced in early 2011 in order to eliminate the requirement for leaving pillars behind. Instead of pillars, the CPF must be engineered to provide the required local and regional stability of the extracted cavities (Mgumbwa \& Nester 2014). 


\subsection{Background}

The CPF plant of Frog's Leg mine was commissioned in June 2010 after a mine feasibility study identified a further extension of resources and suggested the value of ore within the pillars justified the use of a $100 \%$ extraction methodology. The underground operations produce approximately 110,000 oz of gold per year, for which an average of $245,000 \mathrm{~m}^{3}$ of void generated must be filled with paste, requiring $343,000 \mathrm{t}$ of dry tailings each year.

\subsubsection{Paste plant}

The dry paste plant's purpose is to mix tailings recovered from a decommissioned tailings storage facility (TSF), cement (low heat) and water to create paste at a rate of $110 \mathrm{~m}^{3} / \mathrm{hr}$ which is transferred to the mined underground voids by gravitational force (Revell 2009).

The plant was designed by Revell Resources and consists of the following (Revell 2009):

- Tailings stockpile and associated roadworks.

- Tailings hopper and feeder system.

- Tailings conveyor.

- Binder storage, transfer and metering system.

- Paste mixing facility.

- Paste hopper.

- Power reticulation within the paste plant battery limits.

- Control room and ablution facilities including all equipment and furnishings.

\subsubsection{Tailings}

When the plant was established, the tailings for the CPF were sourced from Barrick's Kundana TSF facility via a tailings reclamation agreement. The agreement allowed Frog's Leg mine to remove tailings from their old decommissioned tailings dam under certain conditions with the help of haulage contractors. The tailings obtained were tested for their CPF suitability at the Western Australian School of Mines' geomechanics lab (Villaescusa \& Saw 2011).

The particle size distribution (PSD), viscosity, compatibility to cement types and volume, sensitivity to water quality, specific gravity, and mineralogical analysis of the tailings sampled were determined. The PSD of the tailings, as illustrated in Figure 1, complies with the 'rule of thumb' requirement for making CPF by achieving more than $15 \%$ of particles passing 20 micron screen size (Henderson et al. 2005).

These Kundana tailings were the sole source of tailings for the paste plant for approximately five years. After this time, the Kundana tails were replaced by tails from MGO's newly established TSF as discussed in the following sections of this paper. 


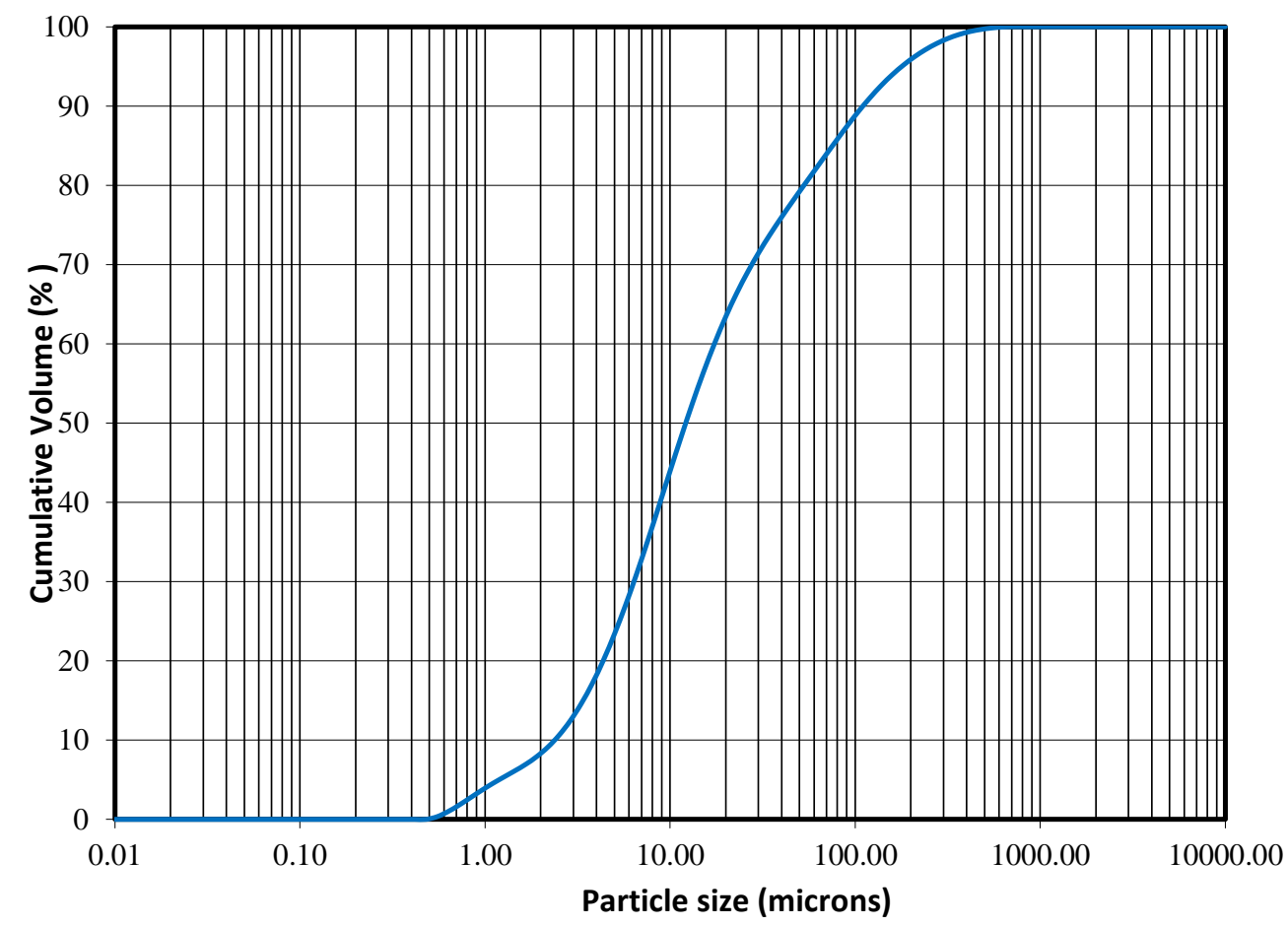

Figure 1 Particle size distribution of Frog's Leg tailings

\subsubsection{Water}

Frog's Leg uses underground hypersaline water with a total dissolved solids (TDS) in excess of $200,000 \mathrm{mg} / \mathrm{L}$ which is five times more than that of average sea water. This has a significant implication on long-term and short-term strength development of the CPF and the type of binder used. Table 1 shows the mineralogical testing results of the Frog's Leg underground hypersaline water.

Table 1 Chemical and mineralogical analysis of hypersaline water (Villaescusa \& Saw 2011)

\begin{tabular}{lll}
\hline Analyte & Quantity & Units \\
\hline $\mathrm{Ca}$ & 722 & $\mathrm{mg} / \mathrm{L}$ \\
$\mathrm{Cl}$ & 110,000 & $\mathrm{mg} / \mathrm{L}$ \\
Electrical conductivity & 19,300 & $\mathrm{~ms} / \mathrm{m}$ \\
$\mathrm{Fe}$ & 0.089 & $\mathrm{mg} / \mathrm{L}$ \\
$\mathrm{K}$ & 341 & $\mathrm{mg} / \mathrm{L}$ \\
$\mathrm{Mg}$ & 10,100 & $\mathrm{mg} / \mathrm{L}$ \\
$\mathrm{Na}$ & 75,500 & $\mathrm{mg} / \mathrm{L}$ \\
$\mathrm{SO} 4$ & 22,000 & $\mathrm{mg} / \mathrm{L}$ \\
Total solids in suspension (TSS) & 12 & $\mathrm{mg} / \mathrm{L}$ \\
TDS & 210,000 & $\mathrm{mg} / \mathrm{L}$ \\
Density & 1.15 & $\mathrm{t} / \mathrm{m}^{3}$ \\
pH & 7.1 & - \\
\hline
\end{tabular}




\subsubsection{Tailings storage facility}

The newly established TSF to be used as the tailings source for CPF is situated $2.5 \mathrm{~km}$ west of the paste plant and $2 \mathrm{~km}$ north of the mill. The TSF was designed, as illustrated in Figure 2, and commissioned by Knight Piésold mid-2014 in conjunction with the mill. The dam was designed to utilise upstream construction for the future lift or expansion which is scheduled yearly. The dam consists of two cells, namely cell one (1) and cell two (2) which are filled alternately by switching in between cells every six months.

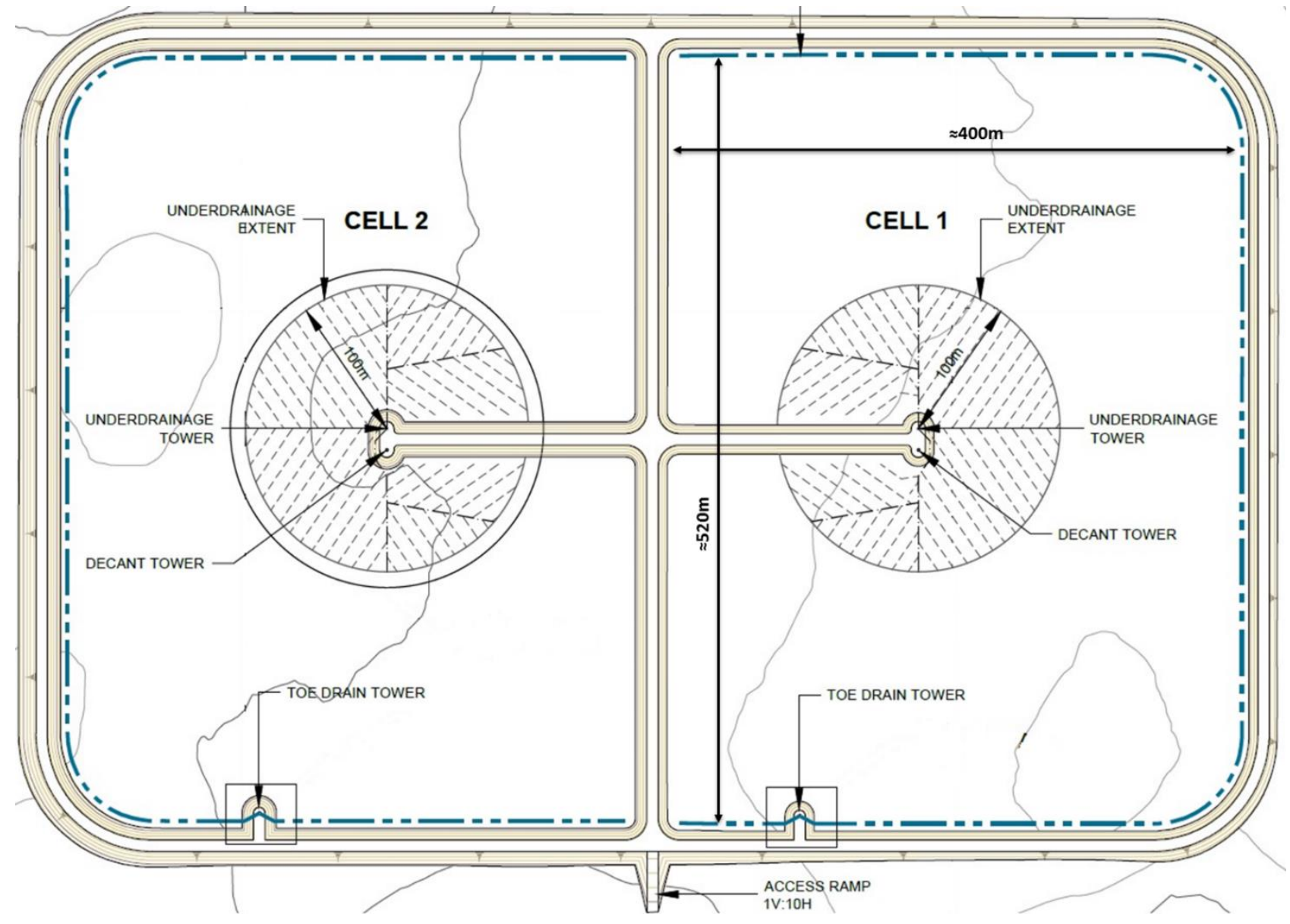

Figure 2 MGO TSF drainage layout (Knight Piésold 2015)

\subsection{Challenges prior to the project}

During the early years, production of consistent quality CPF was challenged primarily due to the inconsistent quality tailings. The Kundana mill processed ore from a variety of open pit and underground sources and periodic campaigns of low-grade stockpile feed and, as such, the deposition of tailings within the TSF was highly variable in quality, particle size and mineralogy. The 'quality' of tailings is largely determined by the amount of fines present and as mentioned previously, as a general rule the tailings should at least have $15 \%$ of passing below 20 microns (Henderson et al. 2005).

The quality of the tailings had an effect on the operation of the paste plant in the following way. The paste plant's reticulation system is designed to run at a maximum operating pressure of $3,000 \mathrm{kPa}$, which is measured from a position $259 \mathrm{~m}$ below surface, at the bottom of an $80^{\circ}$ inclined surface delivery borehole. This borehole is the first leg of a reticulation system that is later routed either side of the orebody as per mine fill requirements. Even though the $3,000 \mathrm{kPa}$ is the designed operating pressure, the operators are strictly advised to the keep the pressure below $1,500 \mathrm{kPa}$ at the bottom of the surface delivery borehole since the pressure of paste, which gets discharged near the open void, will be more prone to the change in pressure head near the stope. 
The tailings from Kundana had clay in it in the form of small lumps. The amount of clay in the tailings affected the operating pressure by altering the moisture of the mix. When the moisture of the tailings feed varies, the density of the fill was getting affected as the moisture governs the water requirement of it (Kuganathan 2005). To manage this volatile situation, the plant operator has to reduce the density of the paste in order to keep the pressure below the specified $1,500 \mathrm{kPa}$, which is predominately managed by increasing the water content of the mix.

In Figure 3, pressure variation at the end of the surface borehole is illustrated over time as seen on the Citech operating system of the plant. Experience at Frog's Leg has shown that when the quality of tailings drops, it significantly impacts the reticulation pressure, and the chances of getting blockages in the paste reticulation system are high when the pressure is inconsistent and rises above 1,500 $\mathrm{kPa}$. In order to minimise the random pressure peaks, the operator will have to reduce the solids concentration which in turn affects the cement:water ratio and therefore the strength development of the paste. If this happens consistently during a pour, the operator will be advised to increase the binder dosage as per the density-to-cement chart designed by the geotechnical engineer. An example of the chart used is shown in Table 2, which is constructed by taking into account the recent CPF results and is modified accordingly as per the production demands. Implementing this table helped with reducing the binder consumption by prioritising certain pours with high and low cement dosages.

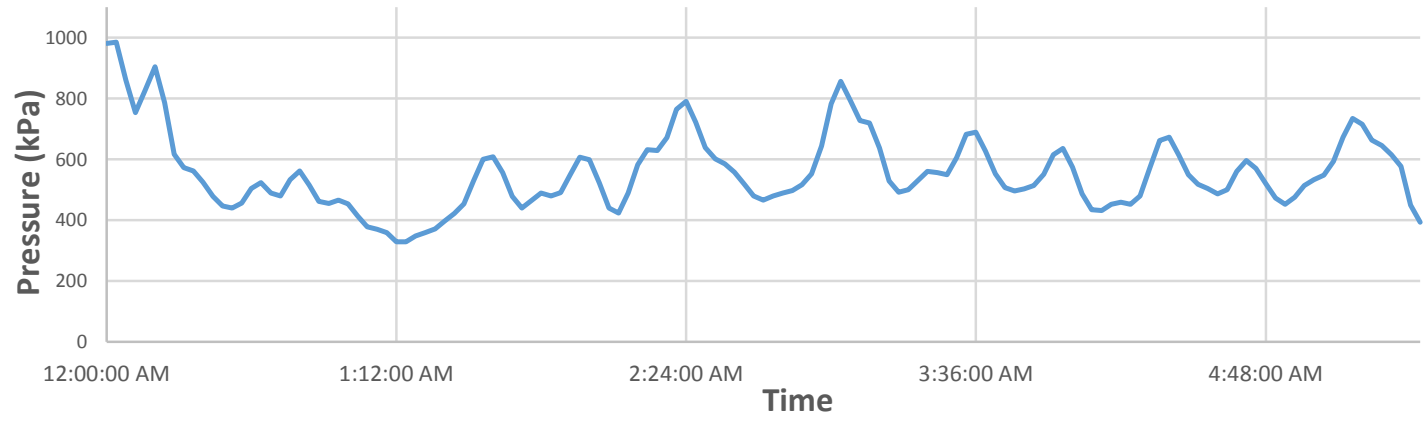

Figure 3 Link drive pressure over time

Table 2 Cement to density table for the operators

\begin{tabular}{lll}
\hline Pour & Solids (\%) & Cement (\%) \\
\hline \multirow{4}{*}{ I } & Less than 67 & 9 \\
& $67-68.9$ & 8.5 \\
& $69-69.9$ & 8 \\
& 70 and above & 7.5 \\
& Less than 68 & 6.5 \\
II & $68.1-69.9$ & 6 \\
& $70-72.9$ & 5.5 \\
& 73 and above & 5 \\
\hline
\end{tabular}




\section{Use of tailings storage facility tailings - project chronology}

The first step of the project to replace the Kundana tailings commenced during late 2014 by sampling the tailings from the newly established TSF. The purpose of the project was to replace the current tailings in place for CPF with freshly harvested tailings from the TSF. The project comprised the components as shown in Figure 4.

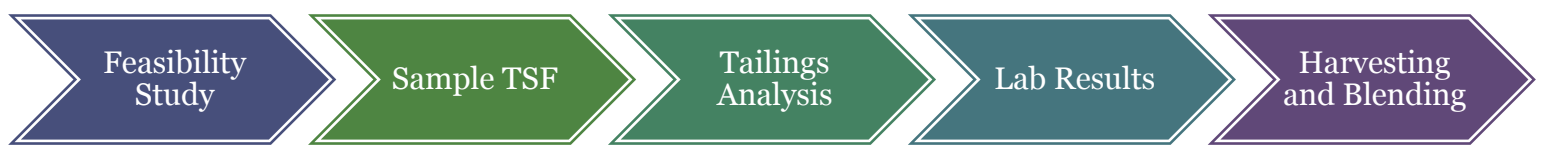

\section{Figure 4 Project chronology}

Feasibility study: An important step in the project was to undertake a feasibility study focusing on comparing different scenarios from which CPF can be produced for the underground requirements. The options investigated included: (i) mechanical harvesting, (ii) geotubes, (iii) filter plant, adjacent to the mill, and (iv) filter plant, adjacent to paste plant (Varvari 2016).

During this study, the main factor considered was the project cost and its implication to the life of the mine and, as such, mechanical harvesting was decided to be the most economical method of tails extraction.

Sample TSF: In this stage, tailings were sampled from the newly commissioned TSF (four months old). The tailings were collected strategically from different spots on each cell from the beach towards the decant of the cell. These spots were later surveyed to understand the deposition and distribution of fines and coarse particles throughout the cell. The samples were sent to an external laboratory for mineralogical analysis and determination of specific gravity and particle sizing via quantitative $\mathrm{X}$-ray diffractometry, and air pyconometer and laser sizing.

Tailings analysis: The results of quantitative analysis and specific gravity (specific gravity $=2.8$ ) of the tailings sampled were the same, irrespective of the location from which it was sampled. The quantitative XRD results are shown in Table 3.

Table 3 Quantitative X-ray diffraction results

\begin{tabular}{ll}
\hline Minerals & Quantity (\%) \\
\hline Quartz & 32 \\
Calcite & $<1$ \\
Halite & 2 \\
Pyrrhotite & 4 \\
Brushite & $<1$ \\
Plagioclase feldspar & 43 \\
Amphibole group & 4 \\
Chlorite group & 6 \\
Mica group & 7 \\
Unknown peak & Unable to be quantified \\
\hline
\end{tabular}

The PSD of the tailings from the beach towards the decant (centre) changed from being coarse to fine since the fine particles in the slurry travel further compared to the coarser one, which settles first near the beach 
upon disposal. During the early stage of the project, the high moisture near the decant of the TSF restricted accessing the tailings from that region.

Figure 5 illustrates the initial PSD of the tailings sampled from different locations within the TSF, and it can be observed that as per the guidelines of more than 15\% of particles passing 20 microns (Henderson et al. 2005), it does not have enough fines in it to produce a desirable CPF product. Consequently, the CPF samples made in the laboratory from this tailings did not attain a satisfactory strength. Also, water bled on top of the sample, since the lack of fines affected the void ratio of the fill after a specific hydration period.

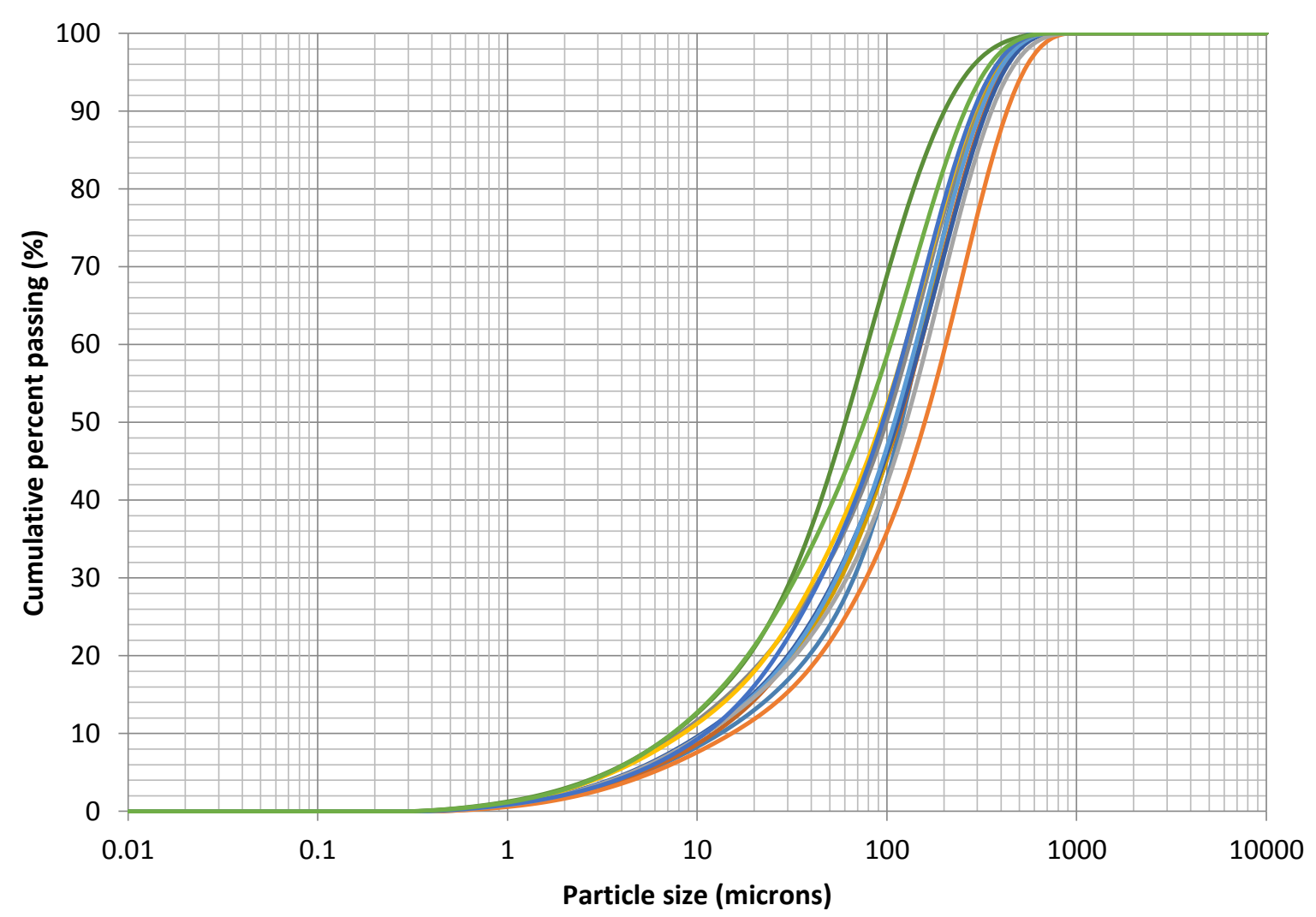

Figure 5 Particle size distribution of tailings sampled from the TSF

Laboratory results: The lab trial was conducted by using the tailings collected near the beach. The samples were tested after 7, 14 and 28 days of cement hydration, during which there was noticeable bleeding of water on top of the samples. This was due to the abundance of coarse particles in the batch which, upon mixing for CPF, the final product will have a high void ratio. This, in turn, leads to water bleeding on top of the sample once it starts hydration. The excess water bled on top of the sample was a concern when considering the same scenario inside an underground void where water sitting on top of the filled stope will cause a requirement for additional pumping capacity or the potential for inflow from water upon exposing the paste for production purposes.

In order to reduce the void ratio of the CPF sample, the tailings were blended with screened overburden (oxide) from MGO's adjacent White Foil open pit operation. As little was documented about the potential performance of this oxide, samples were blended with oxide at different ratios - 60:40, 70:30, 80:20 and 90:10. As anticipated, blending White Foil overburden with the tailings resulted in the PSD showing a greater fine fraction leading to a decrease in the CPF unconfined compressive strength (UCS) and reduction in the amount of bleed water.

Harvesting and blending: As the dam was in operation during tailings harvesting, it was imperative that harvesting of tailings should be carried out in a manner that would not affect the lift cycle. To achieve this, Knight Piésold (KP), who commissioned the TSF, was approached. KP proposed a scope of work which 
overviewed the method to be followed for successfully recovering tailings from the dam by creating borrow pits with the help of low ground pressure (LGP) dozers, pushing the tailings from each cell to transitory stockpiles at the boundary. The proposal laid out by the KP is as follows (and shown in Figures 6 and 7):

- A zone within $10 \mathrm{~m}$ of the TSF's cell boundary (beach) should not be mined as this region is required for the subsequent upstream lift of the respective cell(s).

- The depth of the borrow area should not be more than $1 \mathrm{~m}$ below the existing tailings surface.

- The borrow area should only be mined in bays with each bay's width being in the range of 50 to $60 \mathrm{~m}$ and the beach in between these bays should be at least $5 \mathrm{~m}$ wide.

- The excavation from the borrow areas should be performed in a way that leaves a negative gradient towards the decant of the cell and promotes the flow of water to drain easily. This will assist in settling of the tailings when the next deposition resumes (Knight Piésold 2015).
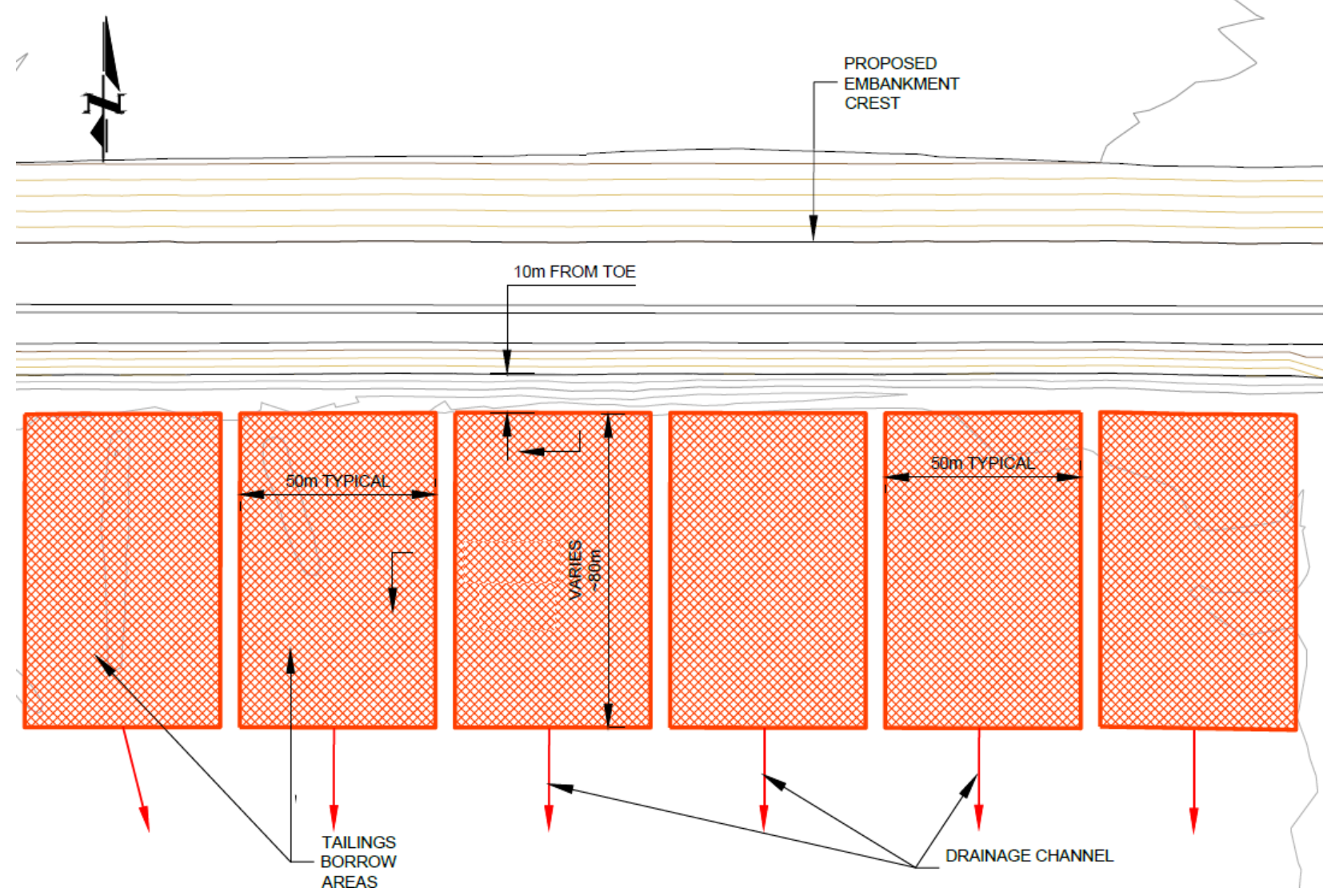

Figure 6 Tailings borrow plan (Knight Piésold 2015)

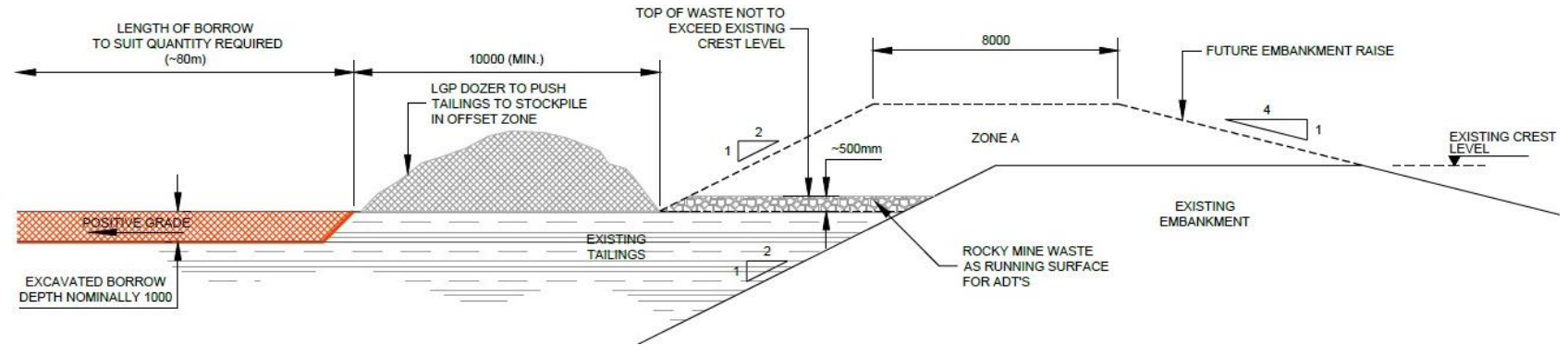

Figure 7 Borrow and embankment configuration (Knight Piésold 2015) 
Harvesting can only be carried out from one of the two cells of the TSF while the other will be active for tailings deposition. The two self-contained cells are built to hold tailings for six months each until the next upstream rise. The schedule put forward by KP is as illustrated in Table 4 which encompasses the raise of the embankment as a part of the TSF expansion cycle.

Table 4 Harvesting schedule (Knight Piésold 2015)

\begin{tabular}{lll}
\hline Month & Cell 1 & Cell 2 \\
\hline 1 & Drying & Deposition \\
2 & Harvesting & Deposition \\
3 & Harvesting & Deposition \\
4 & Harvesting & Deposition \\
5 & Embankment raise & Deposition \\
6 & Embankment raise & Deposition \\
7 & Deposition & Drying \\
8 & Deposition & Harvesting \\
9 & Deposition & Harvesting \\
10 & Deposition & Harvesting \\
11 & Deposition & Embankment raise \\
12 & Deposition & Embankment raise \\
\hline
\end{tabular}

From preliminary calculations, using the proposed KP method, the amount of tailings that can be recovered as per the harvesting schedule was around $65,000 \mathrm{~m}^{3}$ over six months. Annualised, this will approximate to $130,000 \mathrm{~m}^{3}$ of tailings and constitutes only half of the total quantity required by the underground operation which consumes roughly $245,000 \mathrm{~m}^{3}$. The restriction in acquiring no more than $65,000 \mathrm{~m}^{3}$ is due to the lack of sufficient surface compaction near the decant of the cell due to excess moisture in the region.

The lack of fine particles present in the tailings harvested and the shortage in its tonnage required for underground operations prompted the addition of fines in the form of screened waste oxide from the open pit operations. The oxide was blended into the tailings at different ratios and CPF samples were generated.

\subsection{Blending case study}

Blending tailings with the screened oxide was carried out at laboratory level by percentage weighing of tailings with oxide. After blending the samples at respective ratios, its change in PSD at different quotients was assessed. As mentioned in the Handbook of Mine Fill by Kuganathan (2005), the uniformity coefficient $\left(C_{u}\right)$ of the fill material indicates how well the particles will be packed in the deposition. The larger $\mathrm{C}_{u}$ mix will have a completely saturated deposit, and this will, in turn, reduce the amount of binder required for the mix.

The PSD and mineralogical composition of the screened oxide revealed it as a finer product favourable for blending with tailings. The main composition of it is kaolinite (53\%) and quartz (40\%), where the kaolinite affects the CPF mix's slump and compressive strength (Shen et al. 2012). The oxide was blended with the tailings at 40,30, 20 and 10\%. Upon blending the tailings with oxide, the uniformity coefficient of the mix changed to $9.5,12.2,16.3$, and 14 for blends at $40,30,20$ and $10 \%$ of oxides respectively as illustrated in the PSD diagram in Figure 8. 


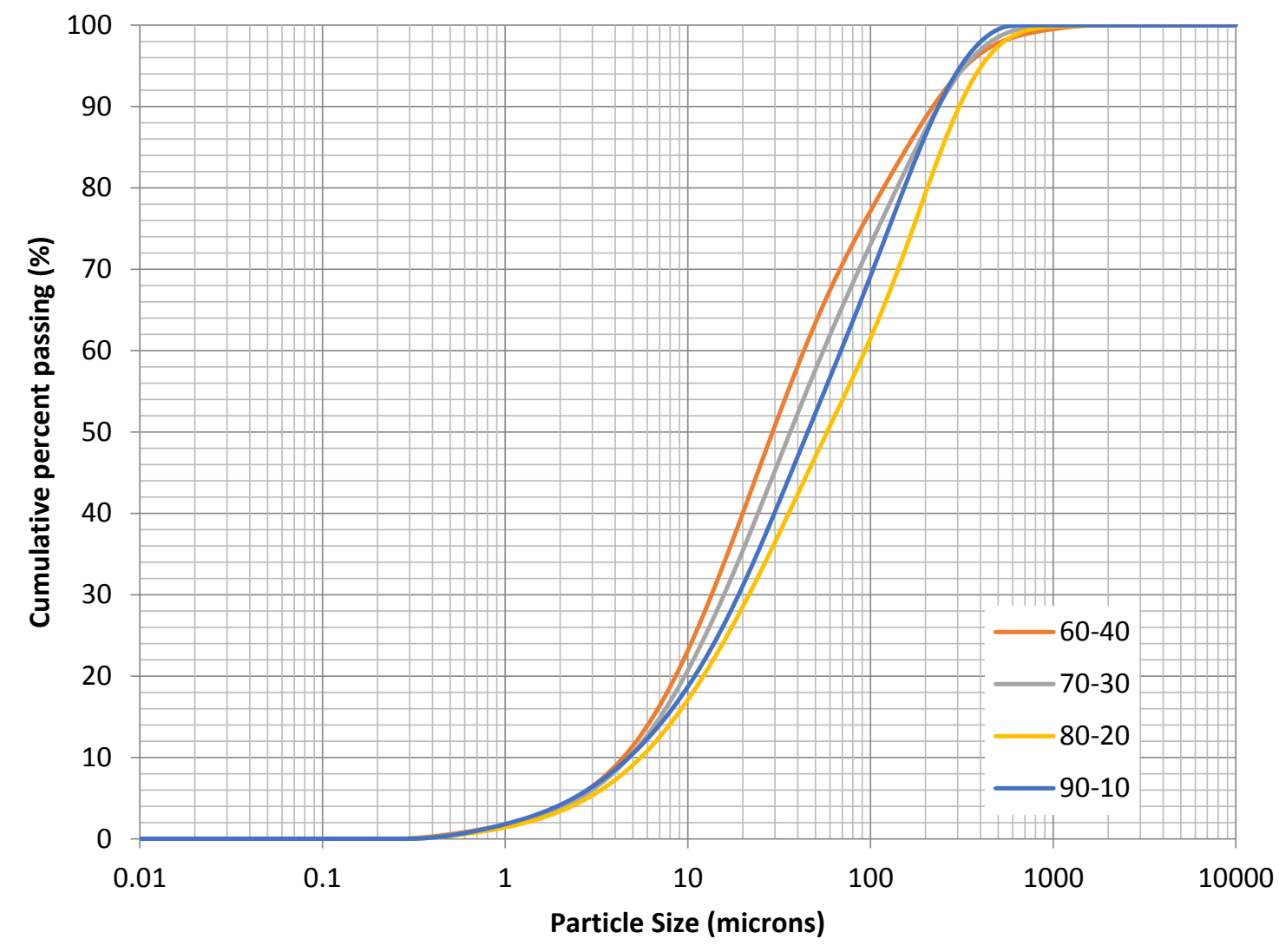

\section{Figure 8 Particle size distribution of tailings mix after blending}

The blend with the highest percentage of oxide (containing kaolinite) produced a CPF mix with the lowest slump. In order to achieve a favourable slump, which determines the flowability of the paste, the density of the mix was reduced, which affected the compressive strength as illustrated in Figure 9.

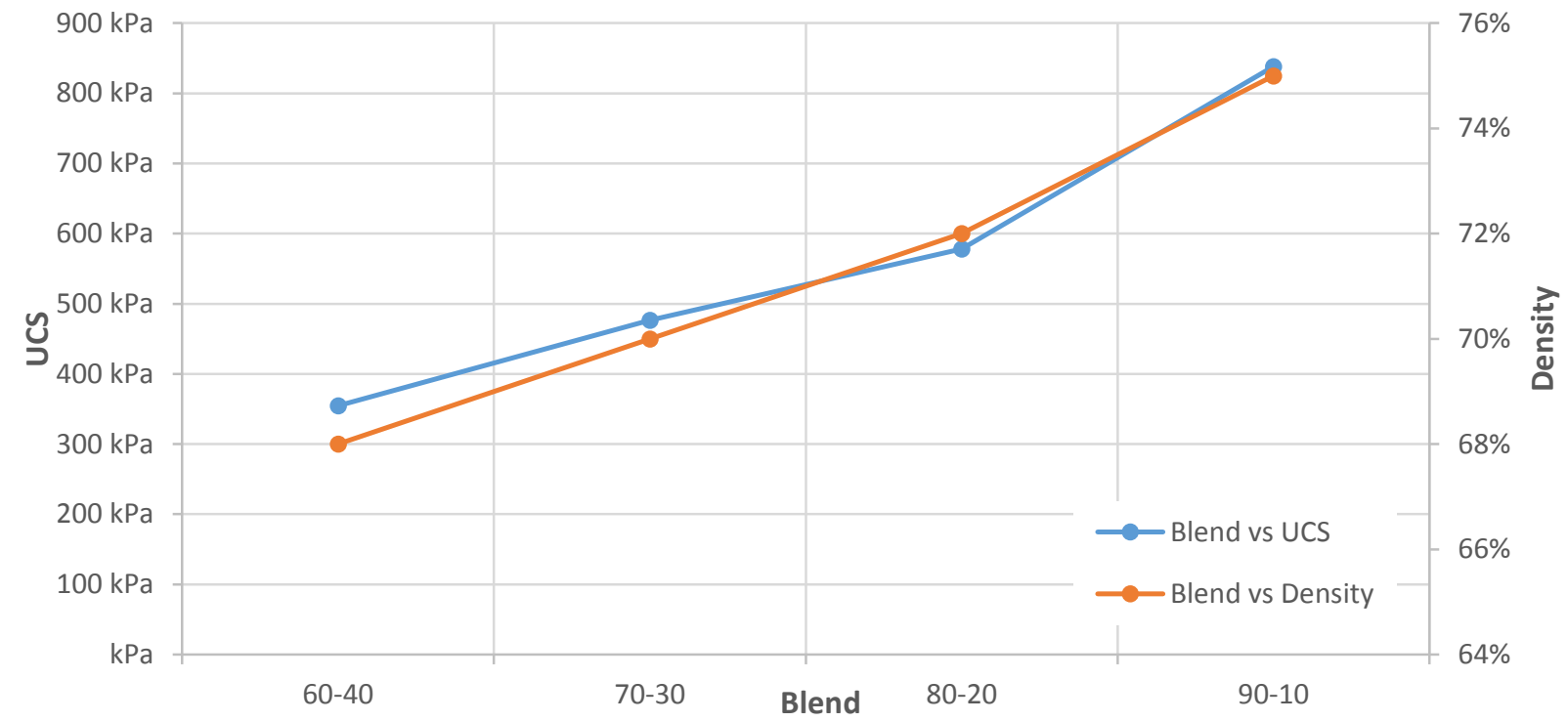

Figure 9 Unconfined compressive strength of CPF mix of different blends at $6 \%$ binder in 28 days 
Of the four blends, the $80: 20$ mix was chosen as the most desirable due to the following reasons:

- The presence of kaolinite (fines) in the oxide ensured a sufficient amount of fines in order to achieve a desirable CPF product.

- The oxide complements the tailings won from the TSF by safeguarding the fill amount required by the underground mining operation.

- A reduction in UCS of the sample at an 80:20 mix can be compensated by increasing the binder dosage. Not meeting the fill requirement, and therefore delaying the mining schedule/sequence, was considered a more significant threat to the operation than an increase in cost associated with additional binder usage.

\subsection{Project execution}

The tailings were extracted from the dam using an LGP dozer which pushed the tailings up in a defined pattern as illustrated in Figure 6. Before commencing the campaign, the specific area to be excavated was demarcated by a surveyor. The dozer worked its way from inside the cell towards the beach, as shown in Figure 10, and pushed the tailings onto the $10 \mathrm{~m}$ beach exclusion zone for later rehandling.

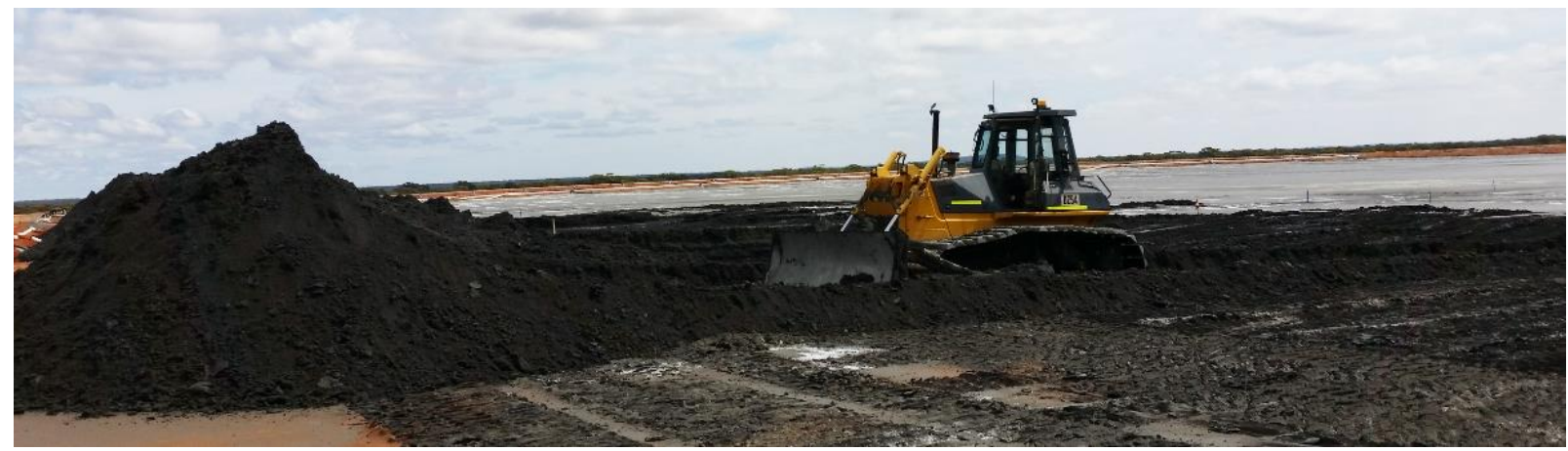

Figure 10 Dozer pushing up tailings

A lot of challenges were faced during the execution stage, especially while preparing the dam before introducing a dozer on top of it. Since the tailings facility was new and the concept of live harvesting was not a consideration during design and construction, the dewatering system capacity caused limitations on dozer mobility inside the dam, especially near the decant region, which was wet. To prevent anyone from assessing the region, a dynamic cone penetrometer was used to check the ground compaction which determined the length of the borrow strip towards the centre of the dam.

Once the campaign of harvesting tailings was complete for one cell, as mentioned in Table 4, the pushed tails are transferred to a pad where they were collected and hauled to the paste plant. The blending process was carried out while loading trucks from the TSF pad using the loader. The haul truck was loaded with tailings and screened oxide at a ratio of 4:1 - one bucket of oxide for every four buckets of tailings. The final blending happened at the paste plant's tailings pad where the unloaded tailings from the truck were pushed and re-handled by loader as part of the daily paste pad operation.

\section{Recent development}

As the harvesting progressed, the dewatering rate was improved by the TSF team for each cell. This aided in allowing access to the region near the decant and, in turn, improved the recovery of tailings from that region which contained more fines. In addition, a small fleet of Moxy trucks was introduced to the harvesting fleet which can tram on top of the tailings without putting much pressure on the ground, thus reducing rehandling of tails and boosting the tails recovery volumes. Due to the increased recovery of tailings with the presence of more fines, the PSD curve changed, as depicted in Figure 11, from 15\% passing 20 microns to $40 \%$ passing 20 microns. 


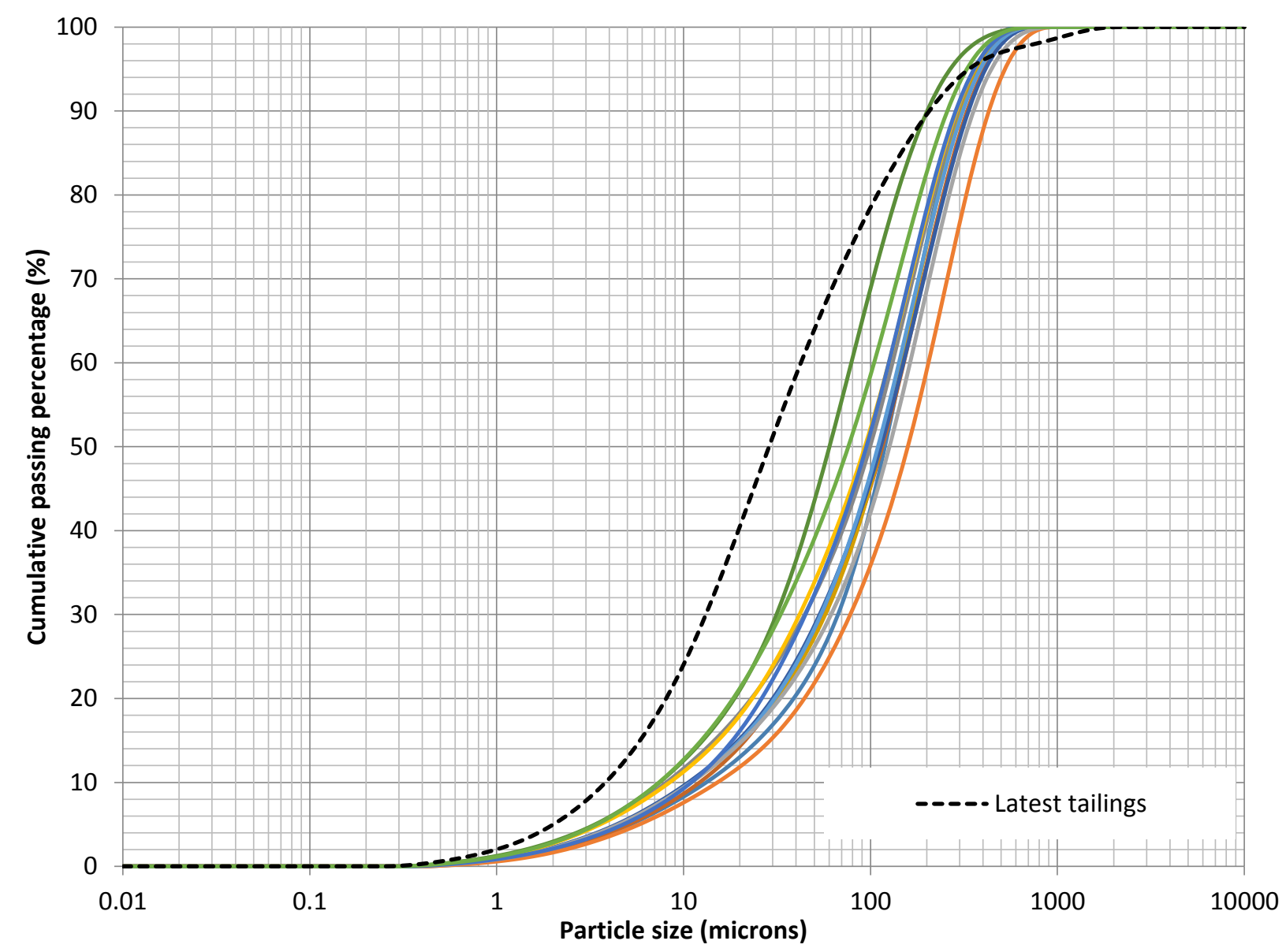

Figure 11 Change in PSDs, latest versus previously sampled tailings

The change in PSD of the harvested tailings in conjunction with the increase in recovery volume from the TSF negated the earlier requirement of screened oxide in the CPF. To examine the potential from this additional harvested material, a trial run of CPF was orchestrated in which a stope was filled with the pure tailings.

\subsection{Observations}

The trial run was conducted by the geotechnical department with the aid of the paste fill department's superintendent. Paste was poured into the stope from the top level which is $515 \mathrm{~m}$ below the surface with the CPF delivery reticulation to this stope being approximately $720 \mathrm{~m}$. The paste plant's response to the fresh tailings was noticeable immediately, with steady pressure reading down the bottom of the surface borehole (within the range of 615 to $1,384 \mathrm{kPa}$ ), which helped in maintaining a good density of paste throughout the pour. The tailings acted as a homogeneous mix due to the absence of oxide which, in turn, helped achieve a steady moisture content. The operator was able to contain the density of paste between 73.4 and $74 \%$ with minimal intervention despite this run of reticulation having numerous vertical-horizontal transition points.

Samples were collected during the pour from both surface and underground simultaneously. They were tested after 7, 14 and 28 days. The sample tests came back with strength in excess of what had been previously achieved with the blended oxide samples as shown in Figure 12. The paste inside the stope was visually inspected from the level above for any segregation of water on top of paste after the pour. There was no visible water segregation on top of the paste after two days, which suggests that the minimum void ratio required for paste is achieved from the current finer tailings. 


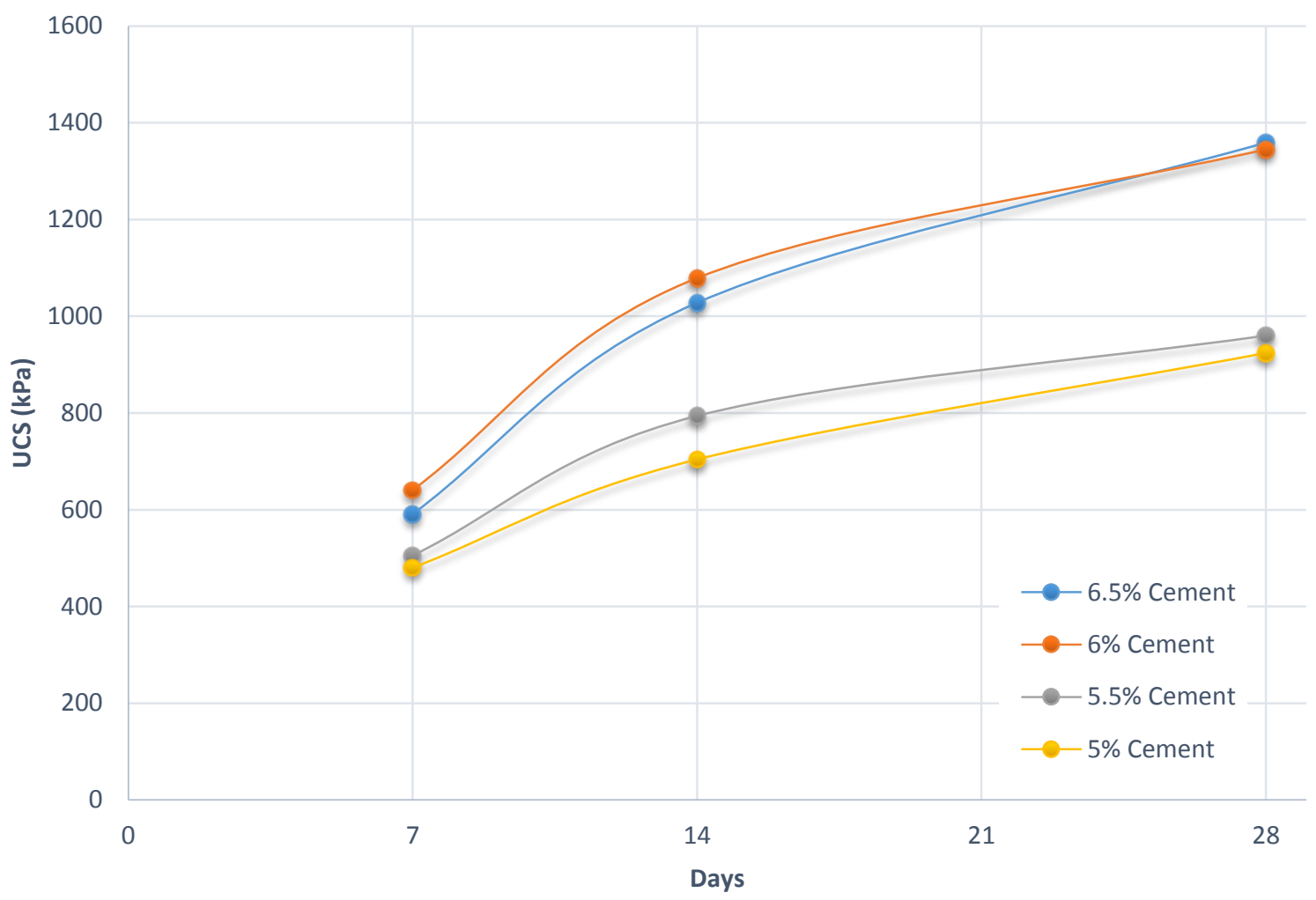

Figure 12 Unconfined compressive strength with straight tailings

\section{Conclusion}

The project spanned over two years which comprises of a detailed feasibility study along with an extensive range of in-house laboratory tests conducted by the geotechnical department to repeal and replace existing Kundana tailings. Four different options to gather tailings from the TSF were studied in detail - mechanical harvesting, geotubes, filter plant adjacent to mill, and filter plant adjacent to paste plant. Out of the four options discussed, mechanical harvesting was the most suitable choice when considering the financial burden it will have on the remaining mine life. The shortcomings in acquiring enough tonnage of tailings from the TSF, at the beginning, compelled the team to look for alternatives which could fulfil the underground fill requirement. Screened oxide (waste overburden) from the open pit operation was handpicked because of its potential to satisfy the fill requirements, both quantitatively and qualitatively. Lots of quality control testing was conducted onsite (by the geotechnical department) and offsite (by consultants) to confirm this and to find the most feasible blend for CFP.

Over time and with the addition of experimental learnings, the harvesting techniques improved, which resulted in the superior recovery of tailings from the TSF, and this modified the tailings PSD. The harvesting team was able to acquire more fines which assisted in eliminating the substituted oxide from the tailings mix. This benefited the company by eliminating the obligation to acquire screened oxides, a reduction in binder content and other associated rehandling activities. The project was executed with utmost diligence by tracking each step from the very beginning to the day of the first pour with the blended tailings. Going forward, the main focus will be to make sure the tailings procured is consistent with regard to its PSD, which is dependent on the harvesting method laid out by consultants. Overall this report has presented the obstacles overcome by a small site technical team when it comes to harvest tailings from an active TSF and discusses the possibility of modifying it for the CPF mix. 


\section{Acknowledgement}

The authors express their gratitude towards the Australian Centre for Geomechanics for the opportunity provided to issue this paper. Huge thanks to Matt Varvari, the Development Project Manager at MGO, who steered the project in the right direction throughout. Also, the paste fill department supervisors Greg Rymer and Bob Symes who encouraged and helped in achieving the project goals. Many thanks to Mathew Helinski who provided the technical guidance that was crucial in obtaining the right results.

\section{References}

Henderson, A, Revell, MB, Landriault, D \& Coxon, J 2005, 'Paste fill', in Y Potvin, E Thomas and AB Fourie (eds), Handbook on Mine Fill, Australian Centre for Geomechanics, Perth, pp. 81-97.

Kuganathan, K 2005, 'Geomechanics of mine fill', in Y Potvin, E Thomas and AB Fourie (eds), Handbook on Mine Fill, Australian Centre for Geomechanics, Perth, pp. 21-47.

Knight Piésold 2015, Mungari TSF - Recovery of Tailings from TSF Beach for Paste Backfill, unpublished internal report submitted to Evolution Mining Pty Ltd, Knight Piésold Consulting, Perth.

Mgumbwa, J \& Nester, T 2014, 'Paste improvement at La Mancha's Frog's Leg underground mine', in Y Potvin and T Grice (eds), Proceedings of the 11th International Symposium on Mining with Backfill, Australian Centre for Geomechanics, Perth, pp. 281-294.

Revell, M 2009, La Mancha Frog's Leg's Paste System Feasibility Study, unpublished internal report submitted to La Mancha Resources Australia Pty Ltd, Revell Resources Pty Ltd, Kalgoorlie.

Shen, JN, Xie, ZX, Griggs, D \& Shi, YZ 2012, 'Effects of kaolin on engineering properties of Portland cement concrete', Applied Mechanics and Materials, vols. 174-177, pp 76-81.

Varvari, M 2016, Long Term Tailings Supply for Paste Fill, unpublished internal memo submitted by Matt Varvari, Development Project Manager, Evolution Mining Pty Ltd, Kalgoorlie.

Villaescusa, DE \& Saw, MHA 2011, Research for Optimisation of Frog's Leg Gold Mine Cemented Paste Fill, unpublished report submitted to La Mancha Resources Pty Ltd, Western Australian School of Mines, Kalgoorlie. 